\title{
POLÍTICAS PÚBLICAS E SUAS PÓS-VIDAS Merecimento e cidadania habitacional no Brasil da mobilidade social*
}

\section{Moisés Kopper}

(D) https://orcid.org/0000-0003-0327-7681

Max Planck Institute for the Study of Societies (MPIfG), Colônia, Alemanha. E-mail: moiseskopper@gmail.com; www.moiseskopper.com.

DOI: $10.1590 / 349913 / 2019$

\section{Introdução}

- Dona Hilda, agora é com a senhora. Por que a senhora quer entrar nos apartamentos?

* A pesquisa que informou este artigo contou com o financiamento do CNPq (bolsa de doutorado, 2012-2016), da Capes (bolsa de doutorado sanduíche, 2014-2015), da Fapesp (bolsa de pós-doutorado, 2016-2017, processo n. 2016/16265-1). Agradeço ao Centro de Estudos da Metrópole (CEM) e ao Max Planck Institute for the Study of Societies (MPIfG) por propiciarem a infraestrutura necessária à escrita deste artigo. Também sou grato a todos aqueles e aquelas, em São Paulo, Porto Alegre, Princeton e Colônia, que leram versóes anteriores deste texto por suas contribuiçóes e sugestóes, bem como aos pareceristas da $R B C S$ por seus comentários. Agradeço de forma especial a dona Hilda e aos membros do Codespa por abrirem suas portas e vidas ao longo do período da pesquisa.

Artigo recebido em 24/03/2017

Aprovado em 13/06/2018
- Por que quero morar? Ué, o Demhab me botou lá pra dentro...

- Mas o que a senhora acha? Como a senhora quer deixar seu apartamento? Bonitinho, pintadinho? Como vai ser?

- Vai ser arrumadinho, quero tudo novinho, não quero levar nada. Quero levar a minha roupa, eu e o meu filho. Só comprei uma geladeira nova, bonita, pra levar. O resto vai ficar tudo lá.

(Reunião da associação comunitária, Porto Alegre, junho de 2014)

Hilda de Lima Chaves tem 93 anos [sic] e participou de todas as reunióes do Residencial Bento Gonçalves. Sempre com um sorriso no rosto, se tornou um dos símbolos da luta pela moradia entre as 160 famílias. Agora realizou seu sonho. "Ai meu Deus, será que meu coração vai aguentar?”, perguntou emocionada ao 
receber as chaves. $\mathrm{O}$ coração aguentou, e ela mostrou o apartamento com orgulho para os fotógrafos presentes no evento.

(Departamento Municipal de Habitação (Demhab), Porto Alegre, 28 set. 2014)

Sentada ao centro de um palco improvisado, diante de uma multidão de centenas de futuros beneficiários da casa própria, dona Hilda movimentava os olhos com voracidade. Suas pernas irrequietas entregavam o excitamento de ser parte daquela experiência, de outra forma bem contido com uma postura ereta impecável.

Não era a primeira nem seria a última oportunidade de dona Hilda ao microfone. A senhora negra de 97 anos havia se convertido em baluarte da mobilizaçáo local por moradia na cidade de Porto Alegre. Desde 2009 ela participava assiduamente das reunióes do Conselho de Desenvolvimento do Partenon (Codespa), uma associação de futuros moradores que ocupara diversos espaços de participação da cidade, como o Orçamento Participativo (OP), para reivindicar unidades habitacionais na esteira do lançamento do programa Minha Casa, Minha Vida (MCMV). ${ }^{1}$ Em seus encontros mensais, não era incomum que membros da comunidade fossem instados a falarem sobre suas expectativas enquanto esperavam pela finalização das obras do Residencial Bento Gonçalves, um empreendimento de 540 unidades habitacionais cuja construção fora iniciada em 2010 e que sofrera várias interrupçóes e atrasos devido a falência de construtoras e invasóes. ${ }^{2}$

Expandindo-se rapidamente pelas vilas ${ }^{3}$ do bairro Partenon, ${ }^{4}$ o Codespa reuniu centenas de famílias interessadas em perseguirem coletivamente o sonho da casa própria. Desde o início, seus líderes estiveram profundamente articulados com a atuação de partidos políticos e se construíram por dentro do governo municipal, em colaboração com secretarias, com empresas construtoras e com representantes da Caixa Econômica Federal. Abraçando e replicando esse modelo de governança difusa, o Codespa e suas atividades de capacitação cidadã e inclusão social tornaram-se um elo importante na maquinaria política do programa habitacional, fazendo chegar, mesmo que seletivamente, os benefícios da política pública aos seus destinatários.

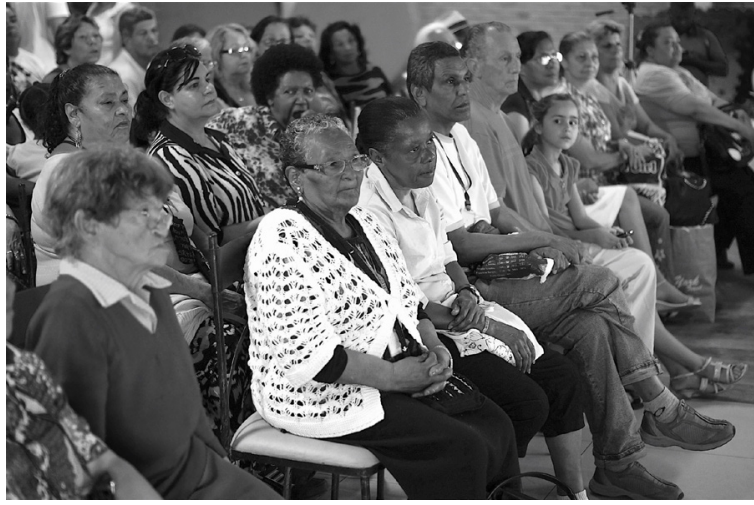

Figura 1 - Dona Hilda em reuniáo do Codespa, em 2014. Fotografia do autor.

Neste artigo, estou interessado em explorar os nexos entre a implementação local de políticas públicas e a produção de mobilidade econômica ascendente na década de 2000. Nesse período, políticas econômicas - como o Plano Real, o aumento real do salário mínimo e a expansão do crédito - e setoriais como os programas de transferência condicionada de renda (como o Bolsa Família) e de habitação social de mercado (como o MCMV) - desempenharam papel preponderante na trajetória de redução das desigualdades de renda no Brasil (Arretche, 2015). A tal ponto que, em 2012, o coeficiente de Gini, indicador clássico de mensuraçáo da desigualdade de renda, caiu para o menor patamar desde 1960 (Paes de Barros, Foguel e Ulyssea, 2007).

Enquanto a literatura concorda sobre os determinantes da queda da desigualdade - e o papel preponderante de políticas sociais e econômicas nessa redução -, não há acordo sobre as consequências taxonômicas e empíricas dessas transformações. Em outra oportunidade (Kopper, 2018), mostrei como economistas, jornalistas, políticos e marqueteiros celebraram a ascensão econômica de milhôes de brasileiros e seu descolamento da pobreza em direção a uma "nova classe média" (Neri, 2008; Sousa e Lamounier, 2010). Definida na releitura de estatísticas nacionais e tornada alvo de intervençóes governamentais e de mercado, a "nova classe média" tornou-se o epicentro de uma assemblage política, econômica e científica que visava recolocar o país no radar internacional do desenvolvimento 
ao desestabilizar crenças arraigadas sobre a pobreza, a desigualdade e a mobilidade, em um país ainda marcado por vastas assimetrias sociais. Apesar das críticas lançadas por sociólogos quanto ao emprego do conceito de "classe" por essa literatura (Souza, 2010; Xavier Sobrinho, 2011; Pochmann, 2012; Scalon e Salata, 2012), a Secretaria de Assuntos Estratégicos da Presidência da República (SAE-PR), em conjunto com institutos de pesquisa de mercado, propôs um novo sistema de estratificação da realidade brasileira que enfatizou e refletiu a expansão desses estratos intermediários da população (SAE-PR, 2012).

Neste artigo, não estou interessado em problematizar as controvérsias acadêmicas em torno do conceito de "mobilidade social", nem os debates taxonômicos sobre a (in)existência de uma "nova classe média" no Brasil da década de 2000. Antes, parto do pressuposto comum a essa literatura - isto é, a constatação da melhoria nos indicadores sociais e econômicos - para inquirir sobre seus efeitos concretos políticos, sociais, econômicos e cotidianos - nas vidas de pessoas como dona Hilda. Apontada por tal literatura como partícipe da "nova classe média baixa", dona Hilda costurou sua própria trajetória ascendente, criando alinhamentos discursivos com instâncias do mercado e do Estado, e recriando seu próprio devir subjetivo nessa circulação narrativa.

Este artigo indaga: como a trajetória pública e privada dessa senhora negra, de 97 anos, que vive de uma renda de pouco mais de um salário mínimo, pode ajudar a entender alguns dos contornos e ambivalências da mobilidade econômica da década de 2000 , e como esta se fez sentir entre beneficiários-modelo de políticas habitacionais no mesmo período? Maculada pelos infortúnios da vida, dona Hilda é a história incorporada dos limites da presença do Estado e da endêmica desigualdade brasileira. Disposta a abandonar seu passado de agruras e a recomeçar a vida em um apartamento, sua força interior cristaliza o improvável da plasticidade humana: a esperança de deslocar-se na busca por uma vida melhor.

Os trabalhos por cidadania e inclusão desencadeados por dona Hilda na busca pela elusiva melhoria de vida - e sua circulação por espaços políticos, econômicos e comunitários - tornaram-se os alinhamentos centrais de uma engrenagem política, econômica e social específica de implementação da política pública. Para captar os jogos de escala que marcaram as interaçóes de dona Hilda no tempo e no espaço, proponho refletir sobre as pós-vidas das políticas públicas. Com isso, refiro-me aos terrenos difusos em que agentes públicos e privados, racionalidades e instrumentos de governo e esperanças íntimas e comunitárias convergem na criaçấo de contextos de longo prazo em que benefícios estatais são negociados, concedidos e vivenciados por seus beneficiários. Para navegar tais espaços, dona Hilda gestou uma personagem pública, com agência e vida próprias, baseada nas afetaçôes e artefatos que marcaram suas experiências comunitárias e a memória de projetos habitacionais pregressos. Suas palavras revelaram horizontes imaginativos (Crapanzano, 2004) que sustentavam as camadas locais de governo através das quais sua experiência de vida era articulada.

Ativista de seu próprio desejo pela melhoria de vida, dona Hilda engajou-se em um trabalho moral de visibilização de suas necessidades e precariedades, que a transformou na personagem idealizada da política habitacional em Porto Alegre e a inseriu no circuito do consumo e da visibilidade pública. À medida que sua esperança foi objetificada em discursos públicos, dona Hilda recriou-se como pobre merecedora e construiu, assim, um excedente simbólico que terminou por separá-la da massa de pobres urbanos, garantindo o caminho para sua própria inclusão na política pública. Mais do que isso, sua personagem foi celebrada, aclamada, fotografada e procurada por políticos, líderes comunitários e vendedores de lojas em busca da "nova classe média" de carne e osso. Nesse caminho, as palavras narrativizadas (Alberti, 2008) de dona Hilda constituem seu próprio movimento de transformação subjetiva.

Este artigo destrincha as engrenagens sociais - a miríade de personagens, agências, discursos e práticas - que configuraram a melhoria de vida como o horizonte do desejável entre beneficiários da política habitacional. Ele explora como a força interior, os esforços de conexão, e as palavras persuasivas de dona Hilda coalesceram com arranjos locais de participação, convertendo sua esperança em uma espécie de "ativo" a ser perseguido através da organização 
coletiva. De sua presença corriqueira entre membros locais do Codespa à conversáo de sua personagem em figura exemplar dos pobres urbanos brasileiros: explorando a cartografia dessas dobras e fendas (Deleuze, 2007), demonstro como a economia política da mobilidade dos anos 2000 criou raízes na produção de cidadáos-modelo - a rigor, casos excepcionais como o de dona Hilda que, amplificados, operaram como "centros exemplares" (Geertz, 1980) do devir da política e de seus resultados.

O percurso de dona Hilda revela duas facetas importantes e mutuamente complementares das trajetórias das políticas públicas no Brasil: de um lado, ao engajarem coletividades e subjetividades periféricas, sua implementação levou à progressiva expansão dos alvos de governo, até incorporarem vidas de pessoas tradicionalmente alijadas de processos participativos e dos dividendos de intervençóes sociais. De outro, fazendo emergir novas diferenças sociais por meio das arquiteturas difusas e variáveis dessas maquinarias de governança (Marques, 2013), as políticas levaram à territorialização de seus efeitos desiguais pelo tecido da cidade. No cerne desses processos está a noção de merecimento: como uma linguagem moral, exercida simultaneamente nos âmbitos local e institucional, o merecimento joga luz sobre a concessão desigual de benefícios habitacionais e ajuda a entender a criação de novas fronteiras simbólicas entre os pobres merecedores e não merecedores. A cartografia dos fragmentos subjetivos de dona Hilda permite, assim, tecer os caminhos sinuosos do merecimento e esboçar um panorama empiricamente informado dos dilemas concretos suscitados pela mobilidade nesse "novo Brasil para além da pobreza” que foi insistentemente proclamado até o limiar da crise econômica recente.

$\mathrm{O}$ artigo inicia com um deslocamento entre a vida pública e privada de dona Hilda, navegando pela poética de suas palavras e apontando para os caminhos que produziram sua narrativa como beneficiária de políticas públicas. Em seguida, o texto discute a economia moral mais ampla que simultaneamente emoldura e dá vazão às palavras de dona Hilda; a partir de testemunhos públicos de suas necessidades que visibilizam esforços de conexão, o artigo argumenta que a emergência de uma nova figura - o pobre merecedor - permite entender os jogos e articulaçóes de escala entre a implementação de políticas públicas, a ampliação dos alvos de governo e a produção de novas diferenças entre os pobres urbanos. $\mathrm{Na}$ terceira parte, discuto como as histórias de dona Hilda foram capturadas por líderes comunitários, enlaçando-se à sua construção e à reprodução da maquinaria local da política pública. Uma quarta sessão do artigo problematiza o papel desses personagens exemplares na performação de versóes sobre o Estado e sobre sua presença na vida social, explorando como, nesses entroncamentos, a política pública é colocada em marcha e adquire vida própria. Particular atenção é dada à produção local desses modelos como evidências generalizáveis e às economias morais que o alimentam. Na última parte, demonstro como os limites entre personagem e pessoa, entre história e subjetividade, fundamentais na constituição da subjetividade pública e privada de dona Hilda, ajudam a entender as pós-vidas das políticas públicas no Brasil contemporâneo - isto é, seus efeitos qualitativos de longo prazo.

Desde já, parece-me relevante advertir o leitor que desenvolvo meus argumentos com base em encontros etnográficos concretos. Ao longo do artigo, as narraçôes de dona Hilda são apresentadas em versos, de modo a preservar, tanto quanto possível, a poética e o tempo de suas palavras. Com isso náo pretendo exotizar sua história, mas propor que, como histórias citáveis (Alberti, 2008), elas compóem unidades narrativas difíceis de serem reproduzidas em toda sua pregnância sem recorrer ao tempo de suas palavras. Busco, assim também, reconstituir a experiência de afetaçóes (Hamilakis, 2017; Stewart, 2017; White, 2017) e os "mundos vividos” (Quirós, 2014) nos quais essas histórias surgem, tomando a potência da trama etnográfica como cabedal para reflexóes conceituais mais amplas (Fassin, 2015).

\section{Sentimentos públicos e vidas íntimas}

Eu morei mais de trinta anos na Maria da Conceição

Quando fui morar lá não tinha nada!

Não tinha nada!

Não tinha água 
Não tinha pipa

Não tinha luz

Não tinha casa

Não tinha nada

E eu trabalhava

Eu vi o guri ali, pequenininho, o Roberto.

Era um casal amigo meu

Eles fizeram a casa e a gente morou tudo junto

E eu ajudei a criar os filhos dele, tão aí

Me chamam de tia

"Ah, tia, oh, tia, vem cá, tia"

Eles sempre me apoiavam

E tinha bonde, naquele tempo, e ele trabalhava num bonde

Tinha uma menina que eu levava toda semana no médico

Sempre acompanhando eles

E sempre fiquei no morro

As pessoas daquele tempo não têm mais ninguém

Já foi todo mundo

Já morreu

Só eu que tô viva

Mas eu trabalhava

Cinco horas eu tava de pé

Eu trabalhava lá perto das torneiras

Pra ir pra cozinha, pra depois ir pro emprego

A Terezinha e o Beto nasceram ali

Naquela maloquinha pequeninha

Era uma pecinha

Depois a minha patroa descobriu e arrumou

dinheiro da assistência social

Ela comprou as tábuas

Comprou tudo

E aí eles fizeram duas peças, bem direitinho

Bonitinho

A gente não tinha água

Não tinha torneira dentro de casa

Não tinha banho

Não tinha nada

Era tudo direitinho, arrumadinho

E ali que ela casou

Só saiu dali quando casou

Porque ele não podia ficar,

Que ele era da polícia, né, escrivão

Não podia ficar ali

Fomos morar na Botafogo

Moramos cinco anos na Botafogo
Mas na Botafogo a gente fervia

Eu fui também, aluguei uma pecinha pra mim,

Mas não com eles, eu morei sozinha!

Sempre sozinha!

A gente ia pra festas, ia pra baile, eles iam

Às vezes eu acompanhava

Ficava lá sentada na mesa, olhando

Aí ia pro barzinho

Ali a gente se divertia, na Botafogo 5

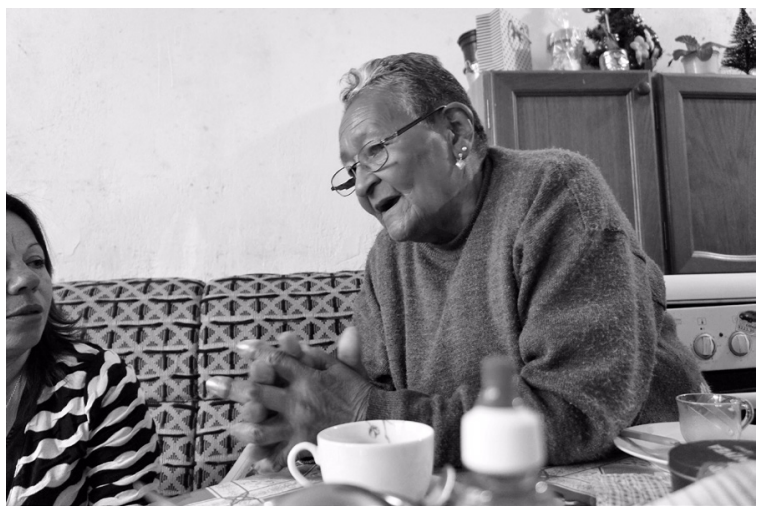

Figura 2 - A contadora de histórias, junho de 2013.

Fotografia do autor.

Dona Hilda fez uma pausa para oferecer café. "Bem quentinho, fiz antes de vocês chegarem", sorriu. Naquela tarde de inverno de 2013 estávamos todos sentados em volta da mesa, farta de comes e bebes, ouvindo as palavras da senhora - uma líder comunitária, uma das filhas de nome Teresinha, o filho Beto.

Em todos esses anos

Eu sempre morava de casa alugada

Quando ficava muito perigoso pra mim morar sozinha no morro

Eu alugava no asfalto

Aí tinha uma senhora de Lavras do Sul

Ela se dava comigo, ela disse:

"Vai pra lá, vai pra lá, lá é bom, tão vendendo, tâo venden $d o$ "

Parece que as pessoas vêm,

Tomam conta,

Depois vendem, invadem 
E depois vendem, baratinho

E eu vou mesmo

Aí eu vim aqui,

Olhei, olhei, olhei,

A tia me deu a chave,

Abriu, gostei

Tava cheio de cal,

Ainda tavam arrumando,

Tinha um buraco ali, minha filha que tapou

"Acho que vou ficar, quanto é aquela casa ali?"

É 400

Eu tinha dinheiro, né?

Eu trabalhava,

Tinha até um dinheirinho escondido, guardado

Passei uma semana com o dinheiro juntinho aqui, na barriga

Eu peguei meu filho mais velho, que morava na Paulino Azurenha

Nós fomos lá

Paguei pra ela

E já me mudei de noite pra cá

Dia 10 de janeiro de 1990

Faz mais de 20 anos que eu tô aqui, né

Eu fico assim, fechadinha

Não vou na casa de ninguém,

Não incomodo ninguém,

Tô aqui fechadinha

Bom dia, boa tarde,

Se tem pessoa doente eu vou,

Se precisa de uma coisa eu ajudo,

Se eu tenho e posso dar,

Eu dou

O que é meu é repartidinho,

É um pão, é um açúcar, é um café, é um arroz,

Eu dou

Eu dou porque Deus me ajuda,

Ele me dá saúde

Que eu tenho bastante, né,

Eu tô com 92 anos e tô assim

Lavo roupa, passo roupa,

Me dá um traje pra ver se eu não engomo,

Tiro de letra!

Em 2009 eles vieram de novo

Eles tavam dando casas!

Dessa vez eu tive que ir em reuniōes

Era um apartamento numa área bem chique

Eu não acreditava que aquilo foi feito pros po- bres,

Mas eu ia nas reunióes

Eu náo tinha nada pra perder

Ali eu vi uma coisa que eu nunca tinha visto antes

Pessoas como eu querendo casa

"Dona Hilda, a senhora vai ser a primeira a entrar no condomínio!"

Mas é claro, eu disse;

$\mathrm{Na}$ minha vida já peregrinei por muito lugar, passei por muita coisa

Agora vou descansar os meus ossos

Do morro eu vou pro asfalto

A plasticidade da vida de dona Hilda, seus altos e baixos, expectativas e desejos, são entretecidos na textura granular do ordinário. Kathleen Stewart escreveu: "[...] o ordinário é um conjunto mutante de práticas e conhecimentos práticos, uma cena de vivacidade e exaustão, um sonho de fuga ou da vida simples" (Stewart, 2007, p. 1, traduçâo nossa). As memórias de dona Hilda - os ciclos de vida que viu passar, suas relaçóes de sociabilidade - são narraçóes que criam passagens e atravessamentos por casas, bairros e projetos habitacionais inacabados. Essa dramatização, no tempo presente, do passado, constrói o futuro como materialidade: uma oportunidade concreta de reinvençáo de si. Como uma borboleta em transformação, dona Hilda edificou um sentido de merecimento - o sonho de finalmente poder mudar-se para o seu apartamento - justificado pelo passado de sofrimentos, mas acionado e agenciado na busca ativa pela mobilidade no presente.

Aqui, convido o leitor a olhar para os fragmentos de sua rotina diária menos como marcadores de "classes populares" do que como fluxos vitais que entretecem a textura do cotidiano. Ao falar de sua sociabilidade por diferentes projetos habitacionais para uma audiência cada vez mais ampla de líderes, políticos e planejadores locais, dona Hilda costurou um sentido público do merecimento que visibiliza as múltiplas agências e afetaçóes que governam seu cotidiano. Sem nunca se deixar capturar pelo Estado - como em uma teia em movimento, cheia de dobras, fissuras e interrupçóes -, dona Hilda deslocou-se sorrateiramente entre políticas públicas e agentes de governo, até tornar-se uma beneficiária do MCMV, em 2009. 
Suas interaçóes cotidianas com burocratas locais, líderes comunitários e agentes de mercado nos convidam a observar a tessitura da presença ubíqua do Estado "na textura minuciosa da vida ordinária” (Gupta, 1995, p. 375, tradução nossa). Na vida de dona Hilda, o Estado é menos uma entidade totalizante (ou biopolítica) do que uma assemblage difusa de forças e intervençóes que se deslocam para abraçá-la em seus braços locais, ainda que sem capturá-la completamente (Das e Poole, 2004). Ao falar dos espaços transitórios de sua sociabilidade, dona Hilda restitui a qualidade artesanal (man-made) (Navaro-Yashin, 2012, p. 31) do Estado, ${ }^{6}$ que transcende sua construção discursiva na cultura pública (Gupta e Ferguson, 2002). Seus travails desafiam a rediscutir a localização e amarração etnográfica do político na antropologia, além de sugerirem que se leve em consideração os domínios afetivos e as experiências subjetivas em que a imaginação é esculpida (Biehl e McKay, 2012, p. 1211) - o que Stewart chamou de "afetos ordinários": "sentimentos públicos que começam e terminam na circulação pública", mas que são também "a substância da qual vidas íntimas são feitas” (Stewart, 2007, p. 2).

Dona Hilda não nasceu em Porto Alegre. Ela mudou-se para a cidade aos dezoito anos, escapando as limitaçóes da vida rural, em busca de trabalho e mobilidade social. Durante a segunda metade do século XX, a maior parte das capitais brasileiras recebeu um influxo massivo de pessoas em circunstâncias similares, sendo rapidamente convertidas em nódulos urbanizados e industriais (para uma perspectiva antropológica desses fenômenos, ver Durham, 1973; Cardoso, 2011). À medida que as áreas centrais adensaram, indivíduos realocaram-se para as periferias e municípios do entorno, criando novos bairros cujo desenvolvimento não foi monitorado pelo Estado. Em Porto Alegre, no início dos anos de 1960, o recém-inventado Departamento Municipal de Habitação (Demhab) conduziu o reassentamento de milhares de famílias para um bairro criado especialmente para acomodá-las, o qual recebeu o nome de Restinga, distante vinte quilômetros do centro da cidade. Até hoje, Restinga segue sendo receptáculo de projetos habitacionais do MCMV em função da abundância de terrenos e de mão de obra barata, em que pese sua infraestrutura precária.
Dona Hilda e muitos outros estabeleceram-se em outro bairro da cidade, o Partenon. Ocupando uma vasta área montanhosa, ele desenvolveu-se longe do radar administrativo de Porto Alegre, alinhado com a história da maior parte das favelas e assentamentos irregulares do Brasil, em que a primeira geração de ocupantes progride e, após mudar-se, "repassa" suas casas para outras pessoas, desencadeando uma espécie de mercado imobiliário informal (Cavalcanti, 2009; Motta, 2014; Valladares, 1978). Ao longo dos anos, dona Hilda esteve constantemente em mudança, ocupando várias casas improvisadas no morro e perto do asfalto. Ela alugava informalmente o espaço ou simplesmente "invadia" projetos habitacionais inacabados e abandonados pela prefeitura.

A esses processos ela se referia pela palavra "enjambrado", que literalmente significa "deformado pela ação do calor ou humidade; dobrado; deformado; permanecer parado por estar fora de posição; ficar preso" (Houaiss, 2009). À maneira do conceito de bricoleur para Lévi-Strauss (1989), as realidades enjambradas de dona Hilda apontavam para uma disputa pela agência - uma tensão entre desistir, permanecer estagnado ou deslocar-se para um futuro melhor através de soluçôes criativas. Em seu contexto de vida, altamente volátil, "ficar preso" referia-se às circunstâncias difíceis e nem sempre controláveis que ela precisava enfrentar para sobreviver.

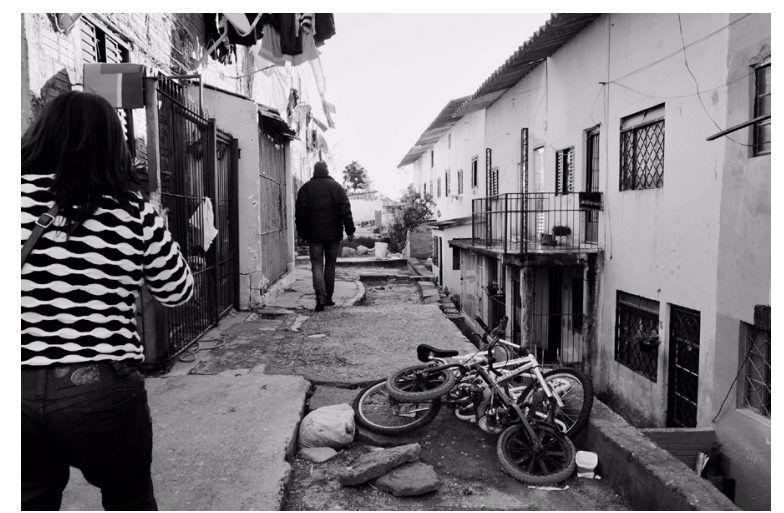

Figura 3 - A caminho de casa, junho de 2013. Fotografia do autor. 
Para navegar o terreno semi-informal e parainfraestrutural (Biehl e McKay, 2012) que conectava dona Hilda às políticas de Estado, ela desencadeou um busca laboriosa por cidadania. "Minha patroa, onde eu trabalhava de cozinheira, descobriu onde eu morava e conseguiu um dinheiro da assistência social", ela me disse. A rica senhora de descendência italiana apresentou dona Hilda ao Estado e a ajudou a registrar-se no banco de dados social em que os necessitados e pobres deveriam aparecer. Foi apenas pouco tempo antes de aposentar-se que dona Hilda foi trabalhar, por oito anos, de carteira assinada, como cozinheira do colégio Luciana de Abreu. "Foi aí que eu paguei o meu INPS. E dali eu saí aposentada”. Sua patroa fora quem lhe arrumara a primeira casa de duas peças depois da maloquinha em que nasceram os dois primeiros filhos. Começava ali o percurso que conectava a subjetividade de dona Hilda à visibilidade das políticas sociais e habitacionais na gestão do espaço urbano.

Quando dona Hilda se mudou da Botafogo, ela foi interpelada pelo Estado novamente. Desta vez, porém, pelo Demhab, que marcara o terreno em que ela recém havia alugado duas peças como área verde. "E área verde não se aluga", ela repetiu. Depois de dois anos de negociaçóes, ela veio a residir com um de seus três filhos em uma casa inacabada, antes de finalmente mudar-se para o Residencial Bento Gonçalves, em setembro de 2014. Aquela casa era parte de uma iniciativa municipal de princípios dos anos de 1990 que não atingira seus objetos de intervenção: os tijolos expostos, cobertos apenas parcialmente de concreto, não deixavam dúvidas. Dona Hilda "comprara" as chaves de uma desconhecida que havia "invadido" o local e agora cobrava alugueis informais de quem quisesse residir. Ela tornara-se a proprietária de uma casa náo documentada, mas visível para o Estado.

Como invasora, movimentando-se nos limites da presença estatal, a vida de dona Hilda era estranhamente monitorada pelo Estado, mas desconhecida pela sociedade. ${ }^{7}$ Registrada no banco de dados sociais do município, a senhora foi beneficiada com uma casinha em um sorteio para outro projeto habitacional do Demhab, assim que se aposentou. Foi lá que teve sua primeira experiência em condomínio. $\mathrm{Na}$ iminência de deslocar-se para a Zona
Sul de Porto Alegre, ela não conseguiu adaptar-se à nova realidade. "Era uma casa de esquina, uma área aberta, térreo. E aquela gurizada noite e dia, pra cima e pra baixo. Já pensou?”, ela me indagou. "Eles chegavam a fazer ganchinhos pra roubar as roupas no varal. Era uma casa bem pequeninha. A sala e o quarto não eram repartidos, a gente é que tinha que colocar tábua. Eu não quis”, concluiu.

Alguns anos se passaram desde a invasão e dona Hilda foi questionada por um representante municipal que perguntou sobre a sua origem. "Eu vim de casa alugada”, ela humildemente respondeu. "Então a senhora vai ficar aqui e se inscrever no Demhab, porque veio de casa alugada e aqui não tem pretendente", os agentes lhe teriam dito. "Foi aí que me mandaram uma carta", dona Hilda continuou, pausadamente, a voz misteriosa. Vinte anos depois, aquela carta daria à senhora a confiança necessária para ir às autoridades e negociar sua entrada no MCMV. "Por causa dessa carta a minha parte tá liberada, eu fiquei inscrita”, ela terminou. ${ }^{8}$

\section{Do testemunho à produção do merecimento}

- Eu quero apresentar para todos os idosos do Brasil e do mundo. Essa aqui é uma guerreira! Nunca faltou a uma reunião, nunca faltou a uma festa! - proferiu, durante inauguração do Residencial Bento Gonçalves, uma líder do Codespa, na direção do prefeito, que a abraçou por longos segundos.

- Vinte anos atrás me chamaram... Me deram essa carta... Guardei, e agora tô recebendo minha casinha...

Nessa economia política, dona Hilda e muitas outras pessoas passaram a usar a própria voz para urdir, testemunhar e demonstrar sua necessidade de lutar e finalmente ganhar a tão desejada casa própria. Como mulher, negra, pobre e idosa, ela era o perfeito retrato corporificado do merecimento; sua simples presença reafirmava o idioma moralizante e humanitário da vida como bem supremo que subjazia aos critérios da política pública. Em 2009, quando foi apresentada por uma amiga ao Codespa, dona Hilda 


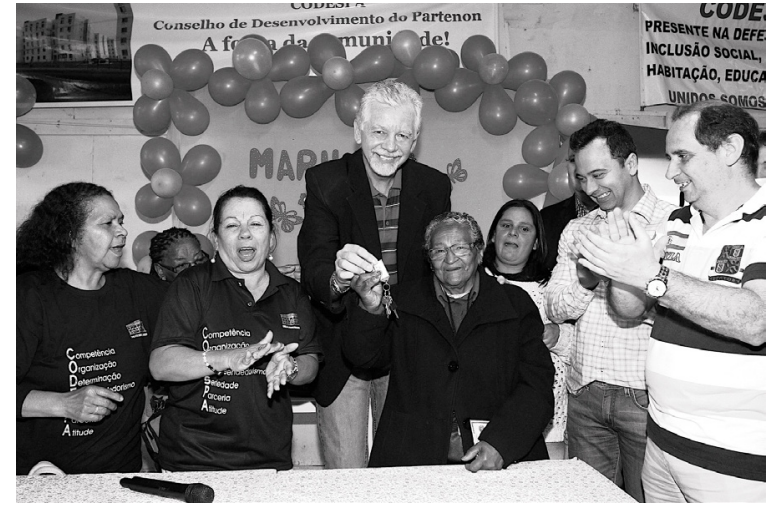

Figura 4 - Dona Hilda aclamada por lideranças, recebendo as chaves do prefeito em 2014. Acervo da Prefeitura Municipal de Porto Alegre.

se deu conta de que, naquele universo em que o número de interessados excedia em muito o número de unidades disponíveis, a concessão do benefício habitacional estava atrelada à habilidade de provar, diante da diretoria do coletivo e da comunidade, com o uso do corpo e da voz, a justeza moral de suas necessidades. "Vidas precárias" eram assim desigualmente "resgatadas" através desse dispositivo de governo que hierarquizava beneficiários segundo a capacidade de que dispunham de colocar sua trajetória em discurso. Nesse trabalho constante por cidadania e conexão, novas formas de subjetivação eram gestadas para demarcar movimentos da precariedade à dignidade, $\mathrm{da}$ vulnerabilidade à inclusão social.

Desde cedo dei-me conta da habilidade de dona Hilda com as palavras e fui em busca de indícios pregressos dessa capacidade demonstrada em discursos públicos. Ela era uma hábil contadora de histórias e era assim que navegava com sucesso esse terreno micropolítico e desigual que articulava política eleitoral, clientelismo, corrupção e idealismo coletivo. Ela aprendeu rapidamente a fabricar histórias endereçadas a uma crescente audiência de planejadores públicos, agentes governamentais, líderes locais e cientistas sociais, incluindo-me entre eles. Dona Hilda desenvolveu a capacidade de experimentar com seu passado para combinar peças de sua vida e recontá -las através do prisma dos projetos em que habitara.

Já em junho de 2011 dona Hilda foi reportada por uma matéria da Prefeitura Municipal de Porto
Alegre (2011) como uma personagem emblemática na "luta" pela habitaçáo. O texto documentou a reunião mensal do Codespa, então realizada no salão paroquial da igreja São Judas Tadeu, que contou com a presença do então prefeito municipal, José Fortunati (então no Partido Democrático Trabalhista, PDT), e do secretário de Governança Local, Cézar Busatto (então no Partido do Movimento Democrático Brasileiro, PMDB). Após apresentar as características infraestruturais dos novos apartamentos, a reportagem concluiu com as palavras de dona Hilda:

“Já estou inscrita. Eu nunca ganhei nada na minha vida. Agora, eu tenho Bolsa Família e vou ganhar a minha casinha', disse dona Ilda de Lima Chaves, noventa anos, na conclusão do seu depoimento cheio de esperança, com aplausos que ecoavam no salão lotado da igreja”. (Idem)

As palavras de dona Hilda eram apontadas como parte de um novo pacto de governança entre as comunidades e o Estado, firmado nas palavras de Busatto: "A coesão de vocês para conquistas dos seus lares é uma ação concreta de governança entre a comunidade e a prefeitura". Abraçando dona Hilda e vários outros membros do Codespa, o secretário cantou a música "Fica mal com Deus", de Geraldo Vandré, ${ }^{9}$ ato documentado em vídeo na internet. ${ }^{10}$ Ainda segundo o texto da notícia, a presidente da associação encerrou o evento, conclamando os futuros beneficiários à "nova vida": "vamos montar as casas com a união da comunidade e apoio da prefeitura para as demandas sociais e junto ao judiciário para beneficiar mais famílias".

Buscando inspiração em seus próprios trabalhos por cidadania e superaçáo da pobreza, dona Hilda transmitia um senso de mobilidade e persecução ativa de melhoria de vida que a separava da massa invisível de pobres urbanos brasileiros. Por isso mesmo, políticos e marqueteiros que buscavam nos projetos habitacionais o emblema de um "novo Brasil", livre da pobreza, vinham capturar suas palavras e tomá-la como representante de uma "nova classe média" em expansão. Desejando e buscando um futuro melhor, o trabalho por cidadania de dona Hilda encontrava 
intersecçóes apropriadas com as expectativas dessas personalidades públicas tão profundamente investidas em afirmar a mobilidade brasileira e seus projetos político-econômicos (Kopper, 2016).

Escutando atentamente as palavras de dona Hilda, percebi que elas continham, também, o desejo por cuidado, reconhecimento e valor político. Essa busca - retratada na imagem do pobre purificado à procura de um cotidiano ordenado e arrumado - criava uma separação em relação à rotina de precariedades, incertezas e esquecimento. Tal faísca de esperança encontrava vasão na expressão de um senso estético e moral específico; afinal, dona Hilda sempre rechaçara a ideia de que, em suas palavras, "pobre precisa andar mal arrumado". A formação desse julgamento era, eu suspeitava, uma consequência de seu convívio de longo tempo com patrôes brancos; por outro lado, era também uma resposta às interaçóes de longa data com políticas de Estado, que usualmente emolduravam os pobres urbanos como imiscuídos em ocupaçóes informais, não civilizados e perigosos. Dona Hilda, por outro lado, se orgulhava da educação que pôde oferecer aos filhos, que nunca deixaram de frequentar a escola graças ao seu esforço em iniciar a rotina diária de trabalho antes mesmo de o sol nascer.

Não tinha água dentro de casa

Não tinha luz

Mas o pessoal dizia assim:

"Ah, os teus filhos parece filho de rico"

Filho de rico por quê?

Porque eles sempre andam bem arrumados?

Ah, mas claro, isso é o capricho da pessoa!

Não precisa ser filho de rico!

Isso é o capricho!

O guarda-pozinho deles

Bem engomadinho

Assim, oh,

Pra eles irem pro colégio.

O corpo tornado político é aqui a fonte primária para a produção de biolegitimidade - isto é, dos jogos que tornam o Estado o garantidor da vida por excelência através de políticas múltiplas e desiguais de concessão de direitos. Em etnografia conduzida na França durante a segunda metade da década de
1990, o antropólogo francês Didier Fassin (2004; 2005) documentou processos semelhantes ao observar as mudanças na gestão e controle de populaçóes que chamou de "precarizadas". Ele mostrou como a adjudicação de auxílios financeiros e a regularização de "indocumentados" colocaram em marcha uma "biopolítica baseada no uso, manejo e na apresentação do corpo diante do Estado" (Kopper, 2014, p. 358). De modo similar, Adriana Petryna, em Life exposed (2013), demonstrou como o Estado passou a conceder proteção social seletivamente a vítimas da explosão química em Chernobyl, desde que provassem que as consequências patológicas eram decorrentes do acidente.

Etnografias brasileiras conduzidas entre "grupos populares" têm apontado sistematicamente para a construção pública e coletiva de categorias como os "pobres" e os "necessitados", visando arregimentar certos bens disponibilizados pelo Estado (Sader e Paoli, 1986; Fonseca, 2000; 2006). Como notou Quirós (2009), as interpretações sobre esses grupos e suas mobilizaçôes políticas tendem a "recortar um ator coletivo" como unidade de análise, associando a este um conjunto de ideias e práticas que os definem em termos de uma identidade política coletiva. Como consequência, a literatura sobre movimentos sociais, embora diversa, tende a privilegiar, metodologicamente, os instrumentos, práticas e narradores oficiais desses movimentos, isto é, aqueles investidos em desenhar os contornos políticos dessas organizaçóes. Uma dos riscos dessa abordagem baseada exclusivamente em estratégias discursivas está em reduzir a diversidade a um exercício taxonômico em que os movimentos passam a ser vistos como atores calculistas e homogêneos. Com isso, perde-se de vista as diferentes escalas internas e externas - em que subjetividades são produzidas e articuladas: à economia e à política; ao Estado e às experiências locais em que afetaçóes íntimas e públicas tomam forma.

Tomo, aqui, a etnografia dos agenciamentos públicos de dona Hilda como ponto de partida para desconstruir as etapas e escalas de sua formação como personagem modelar da história local da política. Suas palavras não são tomadas como indícios acabados e verdades coletivas de um movimento social; ao contrário, o esforço é o de recontextualizá-las 
nos esquemas subjetivos e íntimos para os quais seu engajamento público transborda. Isso permite enxergar como narrativas públicas são construídas em outros espaços e contextos; como tais narrativas são adaptadas e convertidas no processo de construção pública do movimento social; e, por fim, como são performadas para dramatizar o sucesso público de uma intervenção estatal. Ao problematizar os efeitos dessa performação em suas várias escalas, desde a implementação de uma política pública, à existência de coletivos e projetos subjetivos, poderíamos mesmo falar numa espécie de cidadania habitacional, concedida na proporção em que a maquinaria da política pública se alinha às iniciativas locais, recrutando e selecionando cidadãos-modelo como dona Hilda, e criando novas desigualdades entre aqueles nela incluídos e seus novos excluídos.

À medida que eu ouvi dona Hilda repetir sua história em diferentes ocasiōes, ficou claro que, na relação com os políticos e lideranças locais - estes em busca da "nova classe média" de carne e osso -, ela (assim como boa parte do Codespa) continuava a se retratar como pobre. A expectativa, sempre presente, de que era preciso prover testemunhos públicos de suas próprias necessidades e vulnerabilidades, revelava que essa era a forma corriqueira pela qual o Estado e as lideranças locais aproximavam-se das pessoas para decidir sobre a concessão de cidadania habitacional. Ainda assim, dona Hilda esforçava-se em provar que, ao contrário de outros pobres, ou mesmo ao contrário das imagens convencionais que muitas vezes povoavam a mente de intelectuais e políticos sobre a pobreza durante os anos de 1980 e 1990, sua vida era cheia de projetos: mandara os filhos para a escola, criara a família livre de drogas e vícios, trabalhara fora e mantivera a casa limpa e organizada. O benefício habitacional era uma contrapartida justa e merecida pelos anos diligentes de sofrimento e dedicação na busca por uma vida melhor.

A insistente presença da esperança - apesar dos infortúnios e incertezas - configurava-se como o solo fértil a partir do qual um sentido pessoal de merecimento era inscrito. A fabricação cotidiana desse mérito estava associada à participação nas estruturas locais da política pública; o Codespa e sua rotina de reuniōes, eventos e atividades de capacitação, ao fazer chegar os benefícios aos seus destina- tários, convertia a esperança de dona Hilda em artefato de aspiração coletiva. A poética das palavras e a força interior de dona Hilda estavam inextrincavelmente amarradas à economia local da casa própria; seu esforço era o exemplo maior, retratado em histórias e práticas, de que é preciso buscar e lutar pelo benefício, deslocar-se até os espaços e tempos das reunióes, das atividades de fim de semana, dos trabalhos voluntários, das contribuiçóes financeiras, dos almoços e jantares. Ao fim e ao cabo, era a possibilidade, sempre presente, de tornar-se mais merecedor que o vizinho aos olhos escrutinosos da diretoria do Codespa, que suscitava na comunidade o espírito do cidadão ativista. Era necessário conclamar a inclusão social; uma busca laboriosa por cidadania tornava-se, para tanto, crucial.

$\mathrm{Na}$ configuração local do MCMV que encontrei em Porto Alegre, discursos êmicos sobre práticas de merecimento foram acionados para justificar inclusóes e exclusóes de programas habitacionais. Por meio de um intenso trabalho por cidadania e inclusão, além de testemunhos públicos enfatizando o vocabulário da "batalha", da "luta" e do "trabalho", pessoas como dona Hilda criaram aberturas e conexôes com o Estado que visibilizaram suas ansiedades e expectativas de igualdade.

Nesse contexto, a figura do pobre merecedor é fundamental para entender a formação de uma comunidade modelo - baseada no controle e purificação de seus participantes - em meio à presença ambivalente do estado nesses territórios. Oliven (1980) já notou como a Lei dos Pobres, aprovada no reino de Elizabeth na Inglaterra do século XVI, fazia uma distinção severa entre os "pobres merecedores e aqueles que não queriam trabalhar" (Hill, 1974), punindo os "vagabundos robustos" e autorizando a mendicância de "pobres impotentes". Com efeito, pobres merecedores e não merecedores são categorias duais que orientam grande parte das representaçóes do Estado biopolítico em debates públicos sobre os rumos da pobreza (Gupta, 2012, p. 58). Esse processo de objetificação da pobreza também foi documentado por Didier Fassin como "um mecanismo para expor o sofrimento", que pode ser interpretado ainda como um "exercício imposto de subjetivação dos pobres - isto é, de construção do eu como um sujeito à ajuda” (Fassin, 2011, p. 80). 
Por outro lado, o argumento que desenvolvo aqui procura mostrar como a noção de merecimento - e, por extensão, a de pobre merecedor emerge não apenas de interaçóes entre experts e policymakers, cultura pública e mídia, mas também das próprias práticas classificatórias e experiências participativas que caracterizam o cotidiano de implementação de políticas públicas. A produção de uma gramática moral do merecimento encontra ancoragem, simultaneamente, em discursos e práticas nativas e em estruturas sociais mais amplas por meio das quais benefícios habitacionais circulam e são concedidos em âmbito local. Ela se torna, nesse sentido, um operador, tanto técnico quanto pragmático, da implementação da política pública (O’Connor, 2002; Shore, Wright e Però, 2011).

Capturando um sentido coletivo de meritocracia fabricado no cotidiano da participação, a noção de merecimento restitui a agência individual dos beneficiários, engajados ao mesmo tempo na produção de testemunhos públicos de suas necessidades e em alavancar esforços pessoais na busca pela melhoria de vida. Ela permite, nesse sentido, escapar ao dualismo fatalista que caracteriza as explicaçóes da pobreza na literatura de políticas públicas e que vê os pobres como vítimas passivas, ora de sua própria "cultura da pobreza" (Lewis, 1961), ora de forças macroinstitucionais fora de seu controle, como o mercado e o Estado (Neri, 2008; Collins et al., 2009; Daley-Harris e Awimbo, 2011).

Por conseguinte, a pobreza e os caminhos e horizontes de sua superação são aqui entendidos como realidades complexas e multidimensionais (Bengoa, 1995; Martínez Álvarez, 2003; Bayón, 2017) que emergem de um emaranhado simbiótico que passa pela gestáo de populaçóes urbanas, pela entronificação de contextos como endemicamente problemáticos, pelo desenho e implementação de políticas que, finalmente, se cruzam - de modos inesperados e imprevisíveis - com os caminhos, práticas e distinçôes operantes no dia a dia dos próprios sujeitos-alvo dessas intervençôes. Em sintonia com essa definição, a noção de merecimento ilumina tanto os jogos de interesse, poder e influência por trás das estruturas locais de governança da pobreza como as dinâmicas de afetação e subjetivação que essas experiências de exercício da agência simultaneamente suscitam.
O desafio cristalizado na noção de merecimento está, justamente, em ampliar o entendimento dos repertórios de produção do mérito para além do sentido individual de meritocracia comumente associado às classes médias e altas tradicionais. Como é possível pensar nos esforços de dona Hilda sem reduzi-los ao registro da pura troca simbólica desinteressada e benevolente, em que o debate sobre as classes populares, seus modos de vida e economias, muitas vezes é dissolvido -, e ao idioma meritocrático - individual e self-made de auto-percepção das classes médias? Considerando as múltiplas escalas e espaços em que o merecimento é arquitetado e consagrado, é possível reter o senso de agência incorporado aos esforços pessoais de dona Hilda, sem perder de vista que a "conquista" da casa própria figurava como a justa recompensa individual - de um projeto coletivamente orquestrado de construção de uma comunidade modelo para a política pública.

Depois de duas horas de conversas, perguntei sua opiniáo sobre os novos apartamentos:

$\mathrm{O}$ que que eu achei?

Mas o que que eu vou achar?

Mas bah...

O pobre

Ir morar ali?!

Hmmm...

A pessoa tem que ter muita classe, meu filho

Pra morar ali naquele lugar

Um lugar chique, um lugar fino, né?

É fora de série aquilo ali

Vou lhe contar

Eu acho até que vou chorar se eu chegar a entrar lá

Ao ver aquela senhora, né, de cadeira de rodas Que ganhou uma casa da Caixa Federal, anteontem

Deu ali na televisão

Ela chorou, coitada, chorou

Cadeira de rodas e ela ganhou

Tão bonitinho

Ela morava numa casa de tábua

Caindo os pedaços

Entrar numa casa de material

Com tudo direitinho 
Com banheiro, com sala, com cozinha, com tudo...

Ela chorou, e eu também chorei

Olha que eu também vou chorar quando eu entrar lá

Mas claro, já pensou, não é?

Dá uma coisa na gente

Dá uma alegria muito grande no coração da gente, né

Eu vou contar

Com essa idade aqui

Ainda ganhar tudo isso aqui?

A expressão de dona Hilda, "ganhar uma casa", poderia ser sintetizada na ideia de "merecer uma casa", pois sua relação com o Estado era de constante troca. Ela certamente acreditava que tinha o direito de ser uma beneficiária de políticas habitacionais, mas por razóes que em muito excediam as intervençóes macropolíticas e seletivas de governo. Afinal de contas, dona Hilda era uma senhora negra de 97 anos, chefe de família, responsável por um filho parcialmente debilitado, vivendo em uma área condenada pelo Estado como de risco e imprópria para habitaçáo. Mais importante, ela pagava regularmente as mensalidades da associação de que era parte, frequentava assiduamente as reunióes, agradava os líderes locais com presentes, posava para fotos e rendia histórias para o Estado, voluntariou-se como personagem para a matéria jornalística quando o projeto residencial foi inaugurado além de oferecer café e palavras ao antropólogo, em sua casa. O que mais poderíamos esperar de sua laboriosa busca por cidadania?

\section{Da precariedade à dignidade, da vulnerabilidade à inclusão}

"Eu me lembro que ela sentava assim, no tempo em que as reunióes aconteciam no Bar do Getúlio... Eu digo que eram as minhas 'preta veia', elas que seguraram as reunióes, por três anos”, Marília interrompeu a narrativa de dona Hilda. A senhora negra, de cerca de sessenta anos, estatura baixa e voz impostada, construíra sua liderança na circulação pelos espaços da democracia participativa e bastidores da política partidária. Em 2009, para fazer uso do MCMV, criou um novo fórum de participação - o Codespa - convencendo centenas de famílias a perseguirem coletivamente o sonho da casa própria. Desde então, ocupou a presidência da entidade ininterruptamente.

"Não perdia! Com chuva, com vento, nunca", cortou dona Hilda. "Era sempre uma das primeiras", ela bateu com a palma da mão. "A reuniāo era às sete, às quatro já estava ali. A pessoa quer? Tem que lutar! Vai lá, dá o nome e fica deitado? Aí não”, ela foi taxativa.

"É verdade", Marília aproveitou para ressaltar, "sem luta não tem vitória. E aí algumas pessoas apenas depois começaram a ver que era verdade, aí começaram a ir", ela seguiu. "Mas essas mulheres não faltaram nunca a uma reunião. E é uma das questóes de justiça ser contemplada”. Para Marília, dona Hilda cristalizava anos de esforços acumulados na busca por uma comunidade modelo entre os pobres urbanos merecedores.

$\mathrm{Na}$ interlocução com canais públicos, a líder aproveitava para recriar persuasivamente sua principal personagem na luta por habitação, reafirmando a legitimidade dos critérios adotados pelo Codespa na seleçâo dos beneficiários. Assim, repentinamente, dona Hilda assumiu, na voz de Marília, os traços de sua personagem - negra, idosa, mulher, mãe de família, precarizada pelos infortúnios da vida:

A senhora carrega toda a história racial do negro; os escravos a primeira coisa que perderam foi a casa e depois jogaram pro morro. Por que nós não podemos descer do morro até o asfalto? [...] Se é a idade, já tá garantida, mas aí vem a idade, junto com o estado da casa, que é de risco, aí é que eu falo. Aqui se encaixam várias coisas: ela tem um filho que teve acidente, que ela dá assistência, se ele não tivesse com ela, taria sabe aonde, né? Na verdade, não é nem ele que lhe dá segurança, é a senhora que dá segurança pra ele. Então a senhora além de cuidar do filho, teve que comprar uma chave de alguém que invadiu, por não ter casa própria. É assim que eu enxergo.

Em nome do alegado direito moral de fazer justiça, Marília não se furtava, na prática, de fazer ajustes na estrutura de funcionamento do MCMV. 
E resumiu o seu papel como intermediadora na busca pela habitação: "Meu papel foi: tira a dona Hilda do anonimato, traz ela pra visibilidade, pra ela ter esse direito. Porque senão ela nunca taria aqui, ninguém saberia a sua história, se não fossem as reuniōes, se não fossem as entrevistas".

Marília nem bem fez uma pausa para respirar e foi entrecortada por dona Hilda: "Nunca pedi nada pra ninguém! Eu criei meus filhos, e nunca, nunca, nunca... Graças a Deus, tá tudo aí. Ninguém é aleijado, ninguém falta um pedaço, não!”. As imagens elaboradas por Marília para justificar os critérios adotados para o recrutamento de beneficiários tornavam legível à comunidade a agência da burocracia estatal, isentando a líder de responsabilidade política quanto às decisóes que não dependiam exclusivamente de sua "boa vontade". Fronteiras morais eram assim forjadas para balizar e separar os bons dos maus sujeitos, as práticas aceitáveis daquelas condenáveis, os "batalhadores e lutadores" dos que "chegaram ontem".

Diante do antropólogo, da líder comunitária e da família estendida, dona Hilda contou uma história de sucesso e merecimento - que era, também, um capítulo da crônica do MCMV. Ao colocar as necessidades em palavras articuladas, ela enunciava e transformava a vulnerabilidade social em objeto de intervenção estatal. "Por que a senhora gostaria de morar lá se tá adaptada aqui, conhece os cantinhos, mesmo com todas as dificuldades? A senhora acha que lá vai ser melhor?”, Marília provocou, enfatizando que a valorização de uma conquista se dava por meio da efetivação de contrapartidas.

Dona Hilda respondeu à pergunta com os olhos arregalados.

"Ah, porque aqui tem perigo, né! Isso aqui vai cair! Uma senhora que morava ali me disse: 'Vou-me embora daqui porque se isso aqui cair, vai cair por cima da minha casa e vai me matar'. Isso aqui vai cair!”

Repetiu, apontando para as paredes úmidas no fundo da sala. Na passagem da casa de tábua para a casa de alvenaria, era o imaginário da casa própria como vetor de dignificaçáo das vidas precárias que dava sentido à experiência de luta para ganhar o benefício.
$\mathrm{Na}$ economia política da casa própria, idosos como dona Hilda, com percursos pela militância habitacional, tornaram-se ativos importantes. Por atenderem ao maior número de critérios do programa, idosos representavam seu "sucesso" na propaganda local do MCMV e recebiam a titularidade da propriedade do imóvel. Revigorada pela posse do contrato de compra e venda, dona Hilda foi reverenciada pelos filhos por trazer à família a propriedade privada da sonhada casa.

Mas dona Hilda tinha ainda uma importância singular para Marília. Materializando os valores encabeçados pelo Codespa, a senhora ratificava as escolhas da líder - incluindo-se as moralidades envolvidas nas políticas de inclusão e exclusão da política pública. Dona Hilda, através de seu trabalho por cidadania, era a encarnação do próprio movimento físico e subjetivo em direção à construção de uma comunidade modelo. Para Marília, a narrativa dessa trajetória, cheia de planos e desejos, era ilustrativa da transformação operada nas pessoas pela participação em fóruns como o Codespa.

Nessa e em outras conversas, Marília tratou de renovar o desejo de dona Hilda pelo futuro que espreitava, persuadindo-a da necessidade de projetá-lo através de um novo horizonte imaginativo (Crapanzano, 2004). Estimulada pela líder, dona Hilda rememorou os vinte longos anos em que residiu no projeto inacabado do Demhab, que, por ser demasiadamente íngreme e acidentado, era propício a inundaçóes e alagamentos. A senhora tornava-se assim a materialização de um Outro imaginado no tempo e no espaço, e seu movimento físico e subjetivo rumo à nova vida em condomínio era convertido em instrumento de reparação das desigualdades raciais e sociais que assolaram o país ao longo de sua história. Por meio de sensaçóes, sentimentos e opiniôes, os tropos de suas memórias eram restituídos e tornavam-se materialidade concreta para a fabricação da personagem pública que cristalizava o projeto de mobilidade ascendente via políticas públicas do Brasil da década de 2000.

\section{Personagens exemplares}

Sociólogos e filósofos políticos exploraram o papel da justificação e de tecnologias pacíficas - 
como linguagens de ordem, equilíbrio, normas e cultura - na resolução de conflitos em democracias modernas (Habermas, 1991; Boltanski e Thévenot, 2006). Sem discordar desses estudos, argumento que discursos de justificação não apenas garantem a vida em sociedade; eles são também cruciais na criação de fluxos colaborativos entre cidadãos, associações e Estado. Eles agenciam o que a literatura de ciência política sobre pólis nomeou "encaixes": pontos de acesso de atores específicos ao Estado e sua influência nos processos decisórios de políticas públicas (Skocpol et al., 1985; Gurza Lavalle et al., 2012; Carlos et al., 2016). Como tenho proposto (Kopper, 2016; Kopper e Damo, 2018), podemos ainda pensar os testemunhos e justificaçóes de personagens como dona Hilda como eixos em um "alinhamento". Trata-se de um continuum ideológico e moral que revela polarizaçóes e alianças no interior de assemblages: composiçôes - por definição móveis, fugazes e efêmeras - em que convergem discursos científicos, políticos, econômicos, morais e subjetivos de uma época (Collier e Ong, 2005).

A transformaçáo subjetiva de dona Hilda - retratada em histórias, personagens e movimentos tornou-a um alinhamento central para entender os caminhos da mobilidade econômica e seus entroncamentos com políticas públicas. Ela figurou como protagonista de um enlace entre mercado, Estado, ciência e "cidadãos desejantes" (Kopper, 2016). Revisitando o conjunto documentado de interações morais entre planejadores, líderes comunitários, agentes de mercado e outros beneficiários de unidades habitacionais, ficou evidente que ela era a própria incorporação de um novo projeto de país assentado na superação da pobreza e na consolidação de novas subjetividades políticas.

Durante o período da mudança, acompanhei o fluxo de fotos, vídeos e narrativas que circularam pela internet sobre a adaptação de dona Hilda e seu filho ao novo apartamento. Cenas da inauguração a senhora abraçada no prefeito, recebendo de suas mãos a tão esperada chave - se tornaram comuns em matérias de jornal que contavam uma história de lutas pela derradeira habitação. Através do Facebook, novas informações sobrevieram: dona Hilda posava para fotografias, sorridente, recebendo a mobília que havia comprado com o cartão Minha Casa Melhor ${ }^{11}$ diante do caminhão de uma grande loja de móveis e eletrodomésticos com quem Marília firmara parceria para obter descontos, semanas antes.

Meses depois, já em 2015, deparei-me com outro registro midiático que discorria sobre uma visita realizada pelo prefeito a algumas senhoras do Residencial Bento Gonçalves. Novamente, dona Hilda é interpelada pela maquinaria de governança que a convertera em personagem exemplar da política pública: "Eu nunca tive tempo de pensar em mim. Não sabia nem que eu tinha sonhos". Ao prefeito coube parabenizá-la pela "beleza do apartamento", "o interior dos prédios, os canteiros floridos e o playground". Acariciando cachorros e tomando chá com as senhoras, Fortunati lembrava aos merecedores do Codespa do pacto de melhoria de vida firmado durante o ato de inauguração.

Aqui, as vidas públicas de pessoas como dona Hilda operam como "centros exemplares", à maneira do Estado-teatro Negara em Bali do século XIX. Em sua etnografia histórica, Geertz desenvolveu a ideia de que a corte, a capital e sua pompa não eram "o núcleo, o motor ou o pivô do Estado", mas elas eram o próprio Estado (Geertz, 1980, p. 13, tradução nossa). Como o microcosmo de uma ordem supernatural, elas constituíam a realização de um ideal político da ordem social. Sua legitimidade decorria da atualização do mito em espetáculos, cerimônias e dramatizaçóes públicas da regra que reafirmavam a desigualdade social e o orgulho do status. O mito exemplar desse centro de força política visava inibir sua dissolução em camadas dispersas de governo descentralizado e cada vez mais afastadas do modelo clássico de "perfeição".

Qual a natureza da personagem de dona Hilda? $\mathrm{O}$ que ela fazia? Em seu conjunto, a performação coletiva e pública dessas vidas expostas criou centros exemplares que tinham o propósito de modelar os resultados subjetivos da política habitacional para além de seu contexto local. Embora fossem, a rigor, exceções em um emaranhado de beneficiários com baixo grau de "encaixe", sua difusão visava replicar os alinhamentos morais - performados nessas trajetórias públicas - entre cidadãos merecedores e políticas públicas. Elas constituíam esforços para criar um modelo a ser reproduzido em larga escala, 
capaz de superar diferenças locais na implementação da política e alinhavar beneficiários em torno de ideias fundamentais como o merecimento e a dignidade. $\mathrm{O}$ mito de que dona Hilda era peça central e exemplar - cristalizado em cerimônias, rituais e eventos - organizava-se, portanto, na atualização do Brasil como um país menos desigual, mais inclusivo, e do Estado como agenciador dessa mobilidade. Na gestação de personagens, enfim, o próprio Estado performava sua presença e força simbólica.

Acompanhando os lastros desses encontros fortuitos que infundem vida à política habitacional, que tipos de histórias a etnografia permitia registrar? Quais eram os verdadeiros efeitos de longo prazo desses alinhamentos efêmeros e como melhor traçá-los para além de sua pregnância pública? Para resolver esse problema foi preciso regressar, mais uma vez: prenhes de significados abertos e horizontes imaginativos em construção, as palavras de dona Hilda eram um convite ao retorno do etnógrafo aos platôs subterrâneos de fabricação dessa história.

Mas por qual novo pensamento - quais novos personagens? - era plausível esperar, na tessitura desse reencontro? Como seria possível acessar essas zonas morais e imaginativas de subjetivação, não facilmente reveladas, mas que eram o substrato de sua história pública? Estava claro que a descoberta das origens desse desejo de narrar o movimento e de colocar a própria vida em discurso poderia apontar para os limites, ambivalências e contradiçóes do projeto de mobilidade que marcou o Brasil nos anos de 2000.

Essas são, também, apostas em nossas "lanternas empíricas" (Hirschman, 1998, p. 88; Biehl e Petryna, 2013) - a etnografia ajuda a captar os gêneros de história que revelam evidências contraintuitivas sobre as grandes questóes de nosso tempo.

\section{Uma pessoa popular}

Em janeiro de 2015, dois anos após meu primeiro contato com dona Hilda, regressei a Porto Alegre para visitar algumas das famílias em seus novos apartamentos. Dona Hilda ocupava uma unidade cuja vista dava para a avenida Bento Gonçalves, no térreo. Ela recuperava-se de dores no joelho.
"A gente é de carne e osso e fica doente", lembrou para si própria. Pediu que eu sentasse no sofá, enquanto puxava para si uma cadeira que colocou ao lado da TV, sempre ligada.

Dona Hilda falava com naturalidade e, como de costume, seguiu os fios de sua própria narrativa: conduziu-me por histórias de vizinhos, pontuadas por trocas e empréstimos de comida; lembrou dos primeiros dias no apartamento. "A primeira noite eu dormi no chão!”, ela sorriu.

Nós não tínhamos nada;

Não tinha mesa,

Não tinha prato,

Não tinha cama,

Não tinha fogão

Minha filha trouxe um fogareiro elétrico

Pequenininho

Então a gente se dividia

O que um tinha, convidava a vizinha;

O que ela tinha, nos convidava

Fazia comida, repartia

Era assim

Aquele tom repetido de escassez não me era estranho e me fez recordar de interaçóes pregressas. Dona Hilda reportou atrasos na entrega do cartão Minha Casa Melhor, que levaram a protelaçóes na entrega dos móveis. "Custaram pra vir montar; nem era aquela mesa que eu escolhi, mandaram uma bem...”. Apesar do contratempo, ela não reclamou. "Tinha televisão, eu ficava vendo televisão".

"A senhora se considera uma pessoa popular?", perguntei, referindo-me à repercussão de sua história de vida, da estrutura local de participação às instâncias municipais de execução da política pública. "Eu não. Fico bem quieta". "E aqui no condomínio, como que é?”, prossegui. "Ah, aqui todo mundo vem e me abraça... 'Oi, vó, oi, vó, oi, vó. Me conhecem das reuniōes", ela acrescentou aos risos. Apesar de gostar de visitas, dona Hilda as prestava apenas a um seleto grupo de idosas: "Às vezes vou ali na corcundinha, na olhinho apertado, na outra velhinha lá do fundo...”. As lembranças do Codespa transportaram-na de volta ao episódio da carta que, como sabemos, ela recebeu da prefeitura e guardou por vinte anos. 
Por isso que a minha ficha era a número 1 ,

"Pode botar o nome dela lá que ela náo deve nada pra nós",

"Quem deve somos nós".

E foi assim.

E muita gente ia

Muita gente nâo ia

Muita gente tinha preguiça

Eu não.

Podia chover, vento, sol,

Eu sempre tava lá.

Era jantar aqui

Era jantar lá

Era almoço lá

Tenho tudo as carteirinhas

Pagava tudo.

Tinha gente que não queria pagar dez reais

Eu pagava,

Todos os meses,

O que é dez real, né?

Nas reunióes eu ficava sentadinha,

Olhando o pessoal,

Bem quieta.

Nem falava

Tinha jantar, vamos!

Quanto é o jantar?

Quinze pila

Vamos lá!

Eu não perdia

Bah, eu ia perder?

Eu não tinha nada pra fazer

E passou cinco anos que a gente nem sentiu.

Dona Hilda parecia não se importar com a temporalidade da participação que a transformara em uma personagem emblemática da luta por habitação. Acostumada a ouvir e observar cuidadosamente seu entorno, por anos ela viu nos eventos promovidos pelo Codespa uma oportunidade de explorar novos espaços de sociabilidade. A casa própria e a militância eram apenas a superfície explicitada por políticos e líderes comunitários - de um conjunto de motivaçóes que transportava dona Hilda, em noites de calor ou chuva, para fora de sua casinha e de sua televisão, em direção aos espaços e tempos das reunióes em que novos horizontes imaginativos eram fabricados.
Insisti que falasse sobre a crescente atenção que passara a receber de membros da associação e políticos locais. "A senhora gostava disso? Como a senhora se sentia?"

Não, mas eu falava

Eu falava...

Tinha dias que eu não acreditava

Não sei, acho que não

Pra ali? Nós pobre?

Meio difícil

Ali eu acho que só pra rico

Mas eu vou!

Eu vou em frente!

Se eu não ganhar, se eu perder...

Não perde nada!

Eu ia pela folia

Tava lá no meio da conversa,

Dava risada,

Brincava,

Se eu não ganhar eu não perdi nada

Eu lutei!

Os vizinhos deram-se conta da mudança de vida de dona Hilda apenas quando viram as malas e o caminháo que faria o transporte de seus pertences. Organizado pelo filho, o translado da geladeira, da máquina de lavar, de dois colchóes e das roupas custou-lhes $R \$ 20$. No dia seguinte, alguns deles bateram à porta do apartamento. "Vieram ver se eu tava aqui mesmo!", sorriu. "Eu tive que rir. Eu disse: 'Eu não tenho nada, nem cadeira pra sentar. Mas vamos tomar um cafezinho'. Mas que farra, a manicure veio ver se eu tava aqui de verdade". Outras pessoas fizeram o mesmo no dia que se seguiu à mudança. "Desceu o morro todo" - completou o filho - "vieram, olharam pra gente e riram". "O Beto tava ali na janela e gritou: 'Oi, fulano, eu tô aqui, oh", dona Hilda revelou. "As pessoas não acreditaram. Nem eu acreditava”.

Dona Hilda lembrou com emoção de quando recebeu as chaves das mãos do prefeito. "Tava bonito... Eu ganhei um abraço do prefeito. Um abraço e um beijo. 'Vou dar um abraço nessa nega veia!'”. Seus olhos estavam longe. "O que ele disse pra senhora?", perguntei. "Que eu fosse feliz", resumiu, deixando que o silêncio se encarregasse do 
resto. "E a senhora tá feliz?", prossegui. "Mas e não taria por quê? Agora não ganhei até as cortinas de graça?”. Dona Hilda contou a história de quando distribuíram cortinas no portão do empreendimento e ela fora uma das contempladas. Mirando seu entorno, ela lembrou as experiências associadas à aquisição dos artefatos através do cartão Minha Casa Melhor.

Eu não quero mais nada

Só isso aqui tá bom

Pra que encher a casa?

A gente sendo feliz, com qualquer coisa

Comer bem,

Beber bem,

Dormir bem,

Esse é que é o importante

A cama tá ali

Baaaah

Eu deito pro lado que eu quero

Pra cá

Pra lá

É uma delícia pra dormir

Antes eu tinha uma cama de solteiro

Essa é bem grande

Eu deito atravessado

Boto o travesseiro lá no canto

Ela é bem grande e eu sou pequenininha

Eu me esparramo

Mas ela tá bem esticadinha, bem estendidinha

Pago tudo direitinho

Eu sei fazer tudo direitinho

Eu já guardo todo o dinheirinho

Já recebo

Tudo guardadinho

É tanto pra cá

Tanto pra lá

O que sobra é meu

Não sou gastadora

É isso aqui

Comer bem

Beber bem

Dormir bem

Só isso

A inusitada filosofia de vida que relacionava felicidade, consumo da casa, usos do dinheiro e me- recimento deixou-me quieto por algum tempo. Finalmente, dona Hilda havia encontrado regozijo na conciliação das expectativas nutridas em torno de sua personagem por políticos, marqueteiros e lideranças, e suas próprias aspiraçóes e desejos na busca por uma vida digna. Edward Fischer escreveu que "ambicionar pela boa vida envolve o árduo trabalho do devir [becoming], de tentar viver uma vida que se considera digna, tornando-se o tipo de pessoa que se deseja" (Fischer e Benson, 2006; Fischer, 2014, p. 2, tradução nossa). $\mathrm{Na}$ incessante busca de dona Hilda pela felicidade (Mathews e Izquierdo, 2009) e pela boa vida, ela havia encontrado um ponto de chegada que a apaziguava consigo própria um lugar para "descansar os ossos". Imersa em redes de merecimento e cidadania, em dispositivos de consumo e em novas sociabilidades, eram essas afetaçóes cotidianas que costuravam sua subjetividade. Dona Hilda havia colocado o aparato político, econômico e moral, que a produzira como figura exemplar, à sua disposição.

Trazendo-me de volta à realidade, dona Hilda cortou a narrativa, virou-se na minha direção e convidou-me para o café da tarde que havia preparado especialmente para a visita. Tirou o microfone de seu vestido e sinalizou que aquelas duas horas de trocas, palavras e experiências haviam momentaneamente chegado ao fim.

$\mathrm{Na}$ conversa que se seguiu, dona Hilda agradeceu a Deus pelas benesses em vida, rogando que lhe desse os anos necessários para pagar o apartamento. Sua rotina seguia a mesma - frequentando reunióes do Codespa, da associação de idosos e eventualmente viajando para a praia. Perguntei se com as facilidades advindas da mudança ela poderia aproveitar mais a vida, viajar.

"Só pra praia. Só se eu ganhar. Esses dias eu recebi duas cartas do banco. Mão própria. Tô concorrendo a um prêmio. Quem sabe, não sei. Pode até ser que Deus olhe pra mim e eu ganhe"

Sorriu. A sobreposição entre vida e discurso, história e subjetividade, emprestara a dona Hilda um horizonte imaginativo em que ganhar tornavase a linguagem do merecimento e era motivo de festas. Na saída, o convite ao retorno: "Dia 11 faço 


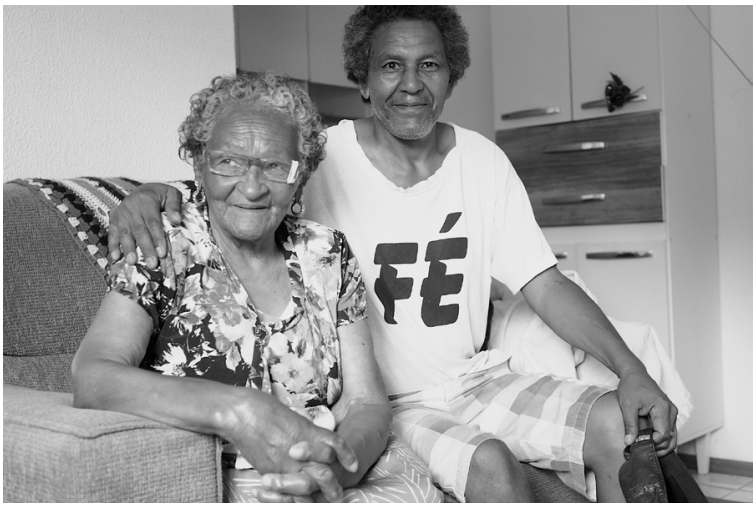

Figura 5 - Dona Hilda e o filho no apartamento, em 2017. Fotografia do autor

94 anos. Vou fazer aquela tortinha de coco. Não carece presente, tô muito velha pra essas coisas. Só quero um abraço das pessoas”.

\section{Consideraçóes finais}

Nos anos de 2000, enquanto o topo da pirâmide brasileira (seus intelectuais, jornalistas, políticos e marqueteiros) discutiu o mérito de categorias analíticas - aquelas mais adequadas para descrever as mudanças em curso na sociedade -, a base da pirâmide debateu-se em torno de outra modalidade de meritocracia: a do acesso às políticas públicas. A definição das fronteiras de quem, afinal, era merecedor, ou de que tipos de investimento (temporais, monetários, subjetivos) configuravam o mérito, ou ainda de quais gramáticas morais eram mais adequadas para justificar o acesso aos benefícios, pontuou o engajamento dos grupos populares com a política e, particularmente, com a experiência de mobilidade ascendente.

Dona Hilda navegou esse terreno difuso construindo-se como uma hábil contadora de histórias. Em nossas conversas e em suas interaçóes com líderes e autoridades, ela era capaz de reconectar fragmentos de sua vida através das experiências e andanças por diferentes projetos habitacionais. A poética de suas palavras e seus esforços de conexão rapidamente chamaram a atenção de uma crescente audiência de agentes envolvidos na implementação da política habitacional e foram tomadas como linguagem arquetípica do modelo de subjetivação a ser perseguido por essas intervençóes. A esperança de dona Hilda a convertera, enfim, no epicentro de uma economia moral mais ampla por meio da qual benefícios habitacionais fluíam e trocas econômicas e políticas cristalizavam.

As experiências e palavras de dona Hilda propunham um desafio: entender a sobreposição entre vida e história, narração e experiência, por trás de seus esforços de conexão. Justapondo histórias contadas em reunióes e eventos, trocas com políticos e lideranças, apropriaçóes midiáticas dessas narrativas e, finalmente, minhas próprias experiências ao longo de anos, foi possível descortinar o trabalho de imaginação moral que levou dona Hilda à visibilidade política, ao desejo por cidadania, à inserção na sociedade de consumo, à recriação do passado e à abertura de um novo futuro de possibilidades. A cartografia desses fragmentos destrinchou o modelo difuso de governança que operou na formação de personagens exemplares como dona Hilda, os jogos de veridição e falsificação por trás de sua performação e os alinhamentos com formaçóes mais amplas do Estado e do mercado.

Os movimentos de dona Hilda expuseram algumas das formaçóes e efeitos de longo prazo da política pública sobre seus beneficiários, para além de sua dimensão pública e política. Destrinchando os mecanismos sociais do merecimento, a etnografia movimentou-se pelas entrelinhas subterrâneas de storytelling normativos, procurando capturar algumas das dobras e interrupçóes da trajetória de dona Hilda. Essas fissuras, ao mesmo tempo que refletiam interações com sistemas de valores e instituiçôes mais amplas, permitiram transcender os discursos de economistas, políticos, marqueteiros e líderes comunitários sobre a mobilidade, descortinando o outro lado - complexo, ambivalente e efêmero - desse "novo Brasil" em transformação.

Obviamente, o caso paradigmático de dona Hilda não esgota a multiplicidade de caminhos possíveis construídos a partir a mobilidade econômica da década de 2000. O que ele ilustra, de modo exemplar, é uma modalidade de alinhamento - por definição efêmero e fugaz - entre interesses políticos, políticas econômico-sociais e práticas 
participativas que transformara radicalmente a arquitetura social das periferias brasileiras e garantira cidadania habitacional a uma parcela significativa da população até então alijada de grande parte de seus direitos sociais. A partir da noção multiescalar de merecimento - e da cartografia dos fragmentos subjetivos de dona Hilda - foi possível observar como essa composição difusa de forças ressonou com as trajetórias e esforços ativos de pessoas concretas engajadas na produção de modelos colaborativos de desenvolvimento econômico e social. A perspectiva longitudinal - no tempo e no espaço - dessas cartografias permitiu enxergar as contradições e interrupçóes da mobilidade ascendente, bem como os efeitos irregulares e multivariados das políticas públicas na vida das pessoas.

A justaposição de vida e personagem aberta pela cidadania habitacional de dona Hilda é também uma metáfora do caráter irrevogavelmente conectado entre horizontes imaginativos, percepçóes de mobilidade e políticas sociais. $\mathrm{Na}$ amálgama de experiências comunitárias, intervenções de mercado, aparatos e camadas de governo, dona Hilda encontrou o espaço subjetivo para atualizar sua dignidade e seus desejos - até então uma possibilidade improvável. Os esforços de subjetivação e imaginação abertos pelas pós-vidas da política pública mostraram-se refratários aos efeitos imediatos da crise econômica e política que se seguiu ao crescimento econômico da década de 2000. Isso não significa que pessoas como dona Hilda não sejam afetadas pelo recesso, mas, simplesmente, que produzem recursos sociais, simbólicos e até certo ponto econômicos, capazes de enfrentar seus efeitos deletérios em novas bases. Os fragmentos subjetivos de dona Hilda aqui narrados ilustram essa busca incessante por reconhecimento social, cuidado e valor político; feixes difusos de histórias que eram o próprio movimento de sua transformação.

\section{Notas}

1 Implementado em 2009, na segunda gestão de Lula (Partido dos Trabalhadores, PT), o MCMV concedeu subsídios a mais de 2,4 milhóes de famílias com renda de até dez salários mínimos, movimentando mais de R 320 bilhôes até 2015 e estimulando a construção civil (Andrade, 2011; Cardoso e Lago, 2013). O MCMV é dividido em três faixas de renda familiar que informam a concessão desses subsídios: Faixa 1 (zero a três salários mínimos, ou R \$ 1,6 mil); Faixa 2 (três a seis salários mínimos, ou R \$ 2,8 mil); Faixa 3 (seis a dez salários mínimos, ou R $\$ 5$ mil). Via de regra, a Faixa 1, objeto deste artigo, é administrada pelas prefeituras, que organizam, dispóem e alocam a demanda segundo critérios do governo federal; essa faixa depende tanto da disponibilidade de terrenos públicos doados pelo município como do interesse de construtoras em propor projetos que se enquadrem nas regras de financiamento da Caixa Econômica Federal.

2 Como mostra a literatura (Bonduki, 2009; Nascimento e Tostes, 2011; Cardoso e Aragão, 2013), falências de construtoras são comuns no MCMV, devido à falta de planejamento, baixa margem de lucro, e pouca expertise de construtoras relativamente pequenas que atuam no ramo.

3 Termo nativo que faz menção a agrupamentos populacionais densamente povoados e de pequena escala, localizadas em diferentes bairros de Porto Alegre. Consideradas "irregulares" pelo Estado, as vilas são resultantes de processos históricos de periferização e urbanização.

4 Criado em 1959, o bairro Partenon ocupa uma área geograficamente central em Porto Alegre. Marcado por grandes contrastes sociais e residenciais, é cortado pela avenida Bento Gonçalves, uma das principais da cidade, e é reduto de universidades, hipermercados e hospitais.

5 Dona Hilda autorizou a publicação dos depoimentos para fins acadêmicos.

6 A ideia, aqui, é que aparatos estatais, burocracias e instrumentos de governo não se resumem a simples construtos racionalizantes, mas são o produto de interaçôes e manipulaçôes humanas e, portanto, exalam afetaçóes sobre as realidades que pretendem descrever e controlar.

7 A invasão era vista como moralmente legítima diante do fato de que dona Hilda "precisava" tanto quanto qualquer outro pobre. Prática amplamente tolerada pela prefeitura, a invasão suspendia os critérios do Demhab e liberava o Estado do custoso trâmite de providenciar habitação social.

8 A carta a que dona Hilda se refere em diversas oportunidades é, de fato, um documento histórico, mas destituído de qualquer efeito legal. O que importa aqui é sua afetação como tecnologia de monitoramen- 
to e classificação dos pobres merecedores, de que dona Hilda se considerava parte.

9 A letra da música mistura religiosidade com transformação subjetiva: "Fica mal com Deus / Quem não sabe dar / Fica mal comigo / Quem não sabe amar / Pelo meu caminho vou / Vou como quem vai chegar / Quem quiser comigo ir / Tem que vir do amor / Tem que ter pra dar / Vida que não tem valor / Homem que não sabe dar / Deus que se descuide dele / $\mathrm{O}$ jeito a gente ajeita / Dele se acabar".

10 Disponível em www.youtube.com/watch?v=S72HZ4zWuO4, consultado em 8/2/2016.

11 Trata-se de uma linha de crédito a juros reduzidos concedida pela Caixa Econômica Federal a cada uma das famílias beneficiadas, com limite pré-aprovado de R\$ 5 mil, para equipar e mobiliar os novos apartamentos.

\section{BIBLIOGRAFIA}

ALBERTI, V. (2008), “'Narrativas pregnantes' como 'jogos de linguagem': possibilidades da história oral à luz da teoria da linguagem de Wittgenstein". História Oral, 11 (1-2): 127-148.

ANDRADE, E. S. J. de. (2011), Politica habitacional no Brasil (1964 a 2011): do sonho da casa própria à minha casa, minha vida. Niterói (RJ), Eduff.

ARRETCHE, M. (org.). (2015), Trajetórias das desigualdades: como o Brasil mudou nos últimos cinquenta anos. Sáo Paulo, Editora Unesp/ CEM.

BAYÓN, M. C. (2017), "Accumulating disadvantages, multiplying inequalities: biographies of poverty in Mexico City". Journal of Poverty, 21 (2): 97-119. Disponível em doi.org/10.10 80/10875549.2016.1141385, consultado em 23/3/2016.

BENGOA, J. (1995), "La pobreza de los modernos". Temas Sociales: Boletin del Programa de Pobreza y Politicas Sociales de SUR, n. 3.

BIEHL, J. (2013), Vita: life in a zone of social abandonment. Berkeley (CA)/Los Angeles, University of California Press.

BIEHL, J. \& McKAY, R. (2012), Ethnography as Political critique. Anthropological Quarterly, 85 (4): 1209-1227.
BIEHL, J. \& PETRYNA, A. (2013), When people come first: critical studies in global health. Princeton (NJ), Princeton University Press.

BOLTANSKI, L. \& THÉVENOT, L. (2006), On justification: economies of worth. Princeton (NJ), Princeton University Press.

BONDUKI, N. (2009), "Do projeto Moradia ao programa Minha Casa Minha Vida". Teoria e Debate, 82: 8-14.

CARDOSO, A. \& ARAGÃO, T. A. (2013), "Do fim do BNH ao programa Minha Casa Minha Vida", in A. Cardoso (org.), O programa Minha Casa Minha Vida e seus efeitos espaciais, Rio de Janeiro, Letra Capital.

CARDOSO, A. \& LAGO, L. C. do. (2013), "O programa Minha Casa Minha Vida e seus efeitos territoriais", in A. Cardoso (org.), O programa Minha Casa Minha Vida e seus efeitos espaciais, Rio de Janeiro, Letra Capital.

CARDOSO, R. (2011), "Favela: conformismo e invenção", in T. Caldeira (org.), Ruth Cardoso: obra reunida, São Paulo, Mameluco.

CARLOS, E.; DOWBOR, M. \& ALBUQUERQUE, M. do C. A. (2016), "Os movimentos sociais afetam as políticas públicas? Respostas (não) encontradas nas principais abordagens". $10^{\circ}$ Encontro da Associação Brasileira de Ciência Política. Belo Horizonte, 30 ago.-2 set.

CAVALCANTI, M. (2009), "Do barraco à casa: tempo, espaço e valor(es) em uma favela consolidada". Revista Brasileira de Ciências Sociais, 24 (69): 69-80.

COLLIER, S. \& ONG, A. (2005), "Global assemblages, anthropological problems", in S. Collier e A. Ong (orgs.), Global assemblages: technology, politics, and ethics as anthropological problems, Oxford/Malden (MA)/Victoria, Blackwell.

COLLINS, D.; MORDUCH, J.; RUTHERFORD, S. \& RUTHVEN, O. (orgs.) (2009), Portfolios of the poor: how the world's poor live on $\$ 2$ a day. Princeton (NJ)/Oxford, Princeton University Press.

CRAPANZANO, V. (2004), Imaginative horizons: an essay in literary-philosophical anthropology. Chicago, University of Chicago Press.

DALEY-HARRIS, S. \& AWIMBO, A. (2011), New pathways out of poverty. Sterling (VA), Kumarian. 
DAS, V. \& POOLE, D. (2004), "States and its margins: comparative ethnographies", in V. Das e D. Poole (orgs.), Anthropology in the margins of the state, Santa Fé, School of American Research Press.

DELEUZE, G. (2007), Two regimes of madness: texts and interviews, 1975-1995. Org. D. Lapoujade. Nova York, Semiotext(E).

DURHAM, E. (1973), A caminho da cidade. São Paulo, Perspectiva.

EVANS, P. B.; RUESCHEMEYER, D. \& SKOCPOL, T. (1985), Bringing the State back in. Cambridge (MA), Cambridge University Press.

FASSIN, D. (2011), Humanitarian reason: a moral history of the present. Berkeley (CA)/Los Angeles, University of California Press.

FASSIN, D. (2015), The public afterlife of ethnography. American Ethnologist, 42 (4): 592-609.

FISCHER, E. F. (2014), The good life: aspiration, dignity, and the anthropology of wellbeing. Palo Alto (CA), Stanford University Press.

FISCHER, E. F. \& BENSON, P. (2006), Broccoli and desire: global connections and Maya struggles in postwar Guatemala. Palo Alto (CA), Stanford University Press.

FONSECA, C. (2000), Familia, fofoca e honra. Porto Alegre, Editora da UFRGS.

FONSECA, C. (2006), "Classe e a recusa etnográfica”, in C. Fonseca e J. Brittes (orgs.), Etnografias da participação, Santa Cruz do Sul (RS), Edunisc.

GEERTZ, C. (1980), Negara: the theatre state in nineteenth-century Bali. Princeton (NJ), Princeton University Press.

GUPTA, A. (1995), "Blurred boundaries: the discourse of corruption, the culture of politics, and the imagined State". American Ethnologist, 22 (2): 375-402.

GUPTA, A. (2012), Red Tape: bureaucracy, structural violence, and poverty in India. Durham (NC)/Londres, Duke University Press.

GUPTA, A. \& FERGUSON, J. (2002), Spatialising states: towards an ethnography of neoliberal governmentality. American Ethnologist, 29 (4), 981-1002.

GURZA LAVALlE, A.; HOUTZAGER, P. P. \& CASTELLO, G. (2012), "A construção polí- tica das sociedades civis", in A. Gurza Lavalle (org.), O horizonte da politica: questôes emergentes e agendas de pesquisa, São Paulo, Editora Unesp/Cebrap/CEM.

HABERMAS, J. (1991), The structural transformation of the public sphere: an inquiry into a category of bourgeois society. Cambridge (MA), The MIT Press.

HAMILAKIS, Y. (2017), "Sensorial assemblages: affect, memory and temporality in assemblage thinking". Cambridge Archaeological Journal, 27 (1): 169-182.

HILL, C. (1974), The century of revolution, 16031714. Nova York, Cardina.

HIRSCHMAN, A. O. (1998), Crossing boundaries: selected writings. Nova York, Zone Books.

HOUAISS, A. \& VILLAR, M. S. (2009), Enjambrado [verbete]. In Dicionário Houaiss da língua portuguesa. Rio de Janeiro, Objetiva

KOPPER, M. (2014), "Nos limites da intervenção: a antropologia crítica de Didier Fassin”. Mana, 20 (2): 355-370.

KOPPER, M. (2016), Arquiteturas da esperança: uma etnografia da mobilidade econômica no Brasil contemporâneo. Tese de doutorado. Porto Alegre, UFRGS,

KOPPER, M. \& DAMO, A. S. (2018), "A emergência e evanescência da nova classe média brasileira”. Horizontes Antropológicos, 50: 335-376.

LÉVI-STRAUSS, C. (1989), O pensamento selvagem. Campinas (SP), Papirus.

LEWIS, O. (1961), Antropología de la pobreza: cinco famílias. Cidade do México, Fondo de Cultura Económica.

MARQUES, E. (2013), “Government, political actors and governance in urban policies in Brazil and São Paulo: concepts for a future research agenda”. Brazilian Political Science Review, 7 (3): 8-35.

MARTÍNEZ ÁlVAREZ, J. A. (2003), Economía de la Pobreza. Madri, Uned.

MATHEWS, G. \& IZQUIERDO, C. (2009), Pursuits of happiness: well-being in anthropological perspective. Nova York/Oxford, Berghahn Books.

MOTTA, E. (2014), "Houses and economy in the favelas". Vibrant, 11 (1): 118-158. 
NASCIMENTO, D. \& TOSTES, S. (2011), "Programa Minha Casa Minha Vida: a (mesma) política habitacional no Brasil". Arquitextos, 133.03 (12).

NAVARO-YASHIN, Y. (2012), The make-believe space: affective geography in a postwar polity. Durham (NC), Duke University Press.

NERI, M. (2008), Microcrédito: o mistério nordestino e o Grameen brasileiro. Rio de Janeiro, Editora FGV.

NERI, M. C. (2008), A nova classe média: o lado brilhante dos pobres. Rio de Janeiro, CPS/ FGV. Disponível em www.cps.fgv.br/ibrecps/ ncm2010/NCM_Pesquisa_FORMATADA. pdf, consultado em 23/3/2016.

O'CONNOR, A. (2002), "Introduction". Poverty knowledge: social science, social policy, and the poor in twentieth-century U.S. history. Princeton (NJ), Princeton University Press.

OLIVEN, R. G. (1980), Urbanização e mudança social no Brasil. Rio de Janeiro, Vozes.

PAES DE BARROS, R.; FOGUEL, M. N. \& ULYSSEA, G. (2007), Desigualdade de renda no Brasil: uma análise da queda recente. Brasília, Ipea.

PETRYNA, A. (2013), Life exposed: biological citizens after Chernobyl. Princeton (NJ), Princeton University Press.

POCHMANN, M. (2012), Nova classe média? O trabalho na base da pirâmide social brasileira. São Paulo, Boitempo.

PREFEITURA MUNICIPAL DE PORTO ALEGRE. (2011), "Mais de 500 moradores do Partenon tratam de habitação". Relaçôes Institucionais e Articulação Política, 23 jun. Disponível em www2.portoalegre.rs.gov.br/smgl/ default.php? P_noticia $=142680 \& M A I S+-$ DE+500+MORADORES+DO+PARTE$\mathrm{NON}+\mathrm{TRATAM}+\mathrm{DE}+\mathrm{HABITACAO}$, consultado em 8/2/2016.

QUIRÓS, J. (2009), "Política e economia na ação coletiva: uma crítica etnográfica às premissas dicotômicas". Mana, 15 (1): 127-153.

QUIRÓS, J. (2014), "Etnografar mundos vívidos: desafíos de trabajo de campo, escritura y enseñanza en antropología”. Publicar, 12 (17): 47-65.

SADER, E. \& PAOLI, M. C. (1986), "Sobre "clas- ses populares" no pensamento sociológico brasileiro", in E. Durham (org.), A aventura antropológica, Rio de Janeiro, Paz e Terra.

SAE-PR - Secretaria de Assuntos Estratégicos da Presidência da República. (2012), Vozes da classe média. Org. D. Grosner, R. Meirelles e D. Gomes. Brasília, SAE-PR.

SCALON, C. \& SALATA, A. (2012), "Uma nova classe média no Brasil da última década? O debate a partir da perspectiva sociológica”. Revista Sociedade e Estado, 27 (2): 387-407.

SHORE, C., WRIGHT, S. \& PERÒ, D. (orgs.) (2011), Policy worlds: anthropology and the analysis of contemporary power. Nova York/Oxford, Berghahn Books.

SOUSA, A. de \& LAMOUNIER, B. (2010), A classe média brasileira: ambiçōes, valores e projetos de sociedade. Rio de Janeiro/Brasília, Elsevier/CNI.

SOUZA, J. (2010), Os batalhadores brasileiros: nova classe média ou nova classe trabalhadora? 2. ed. Belo Horizonte, Editora UFMG.

STEWART, K. (2007), Ordinary affects. Durham (NC), Duke University Press.

STEWART, K. (2017), "In the world that affect proposed". Cultural Anthropology, 32 (2): 192-198.

VALLADARES, L. do P. (1978), Passa-se uma casa: análise do programa de remoção de favelas do Rio de Janeiro. Rio de Janeiro, Zahar.

WHITE, D. (2017), "Affect: an introduction". Cultural Anthropology, 32 (2): 175-180.

XAVIER SOBRINHO, G. G. de F. (2011), "A "classe C" e sua alardeada ascensão: nova? Classe? Média?”. Indicadores Econômicos FEE, 38 (4): 67-80. 


\section{POLÍTICAS PÚBLICAS E SUAS PÓS-VIDAS: MERECIMENTO E CIDADANIA HABITACIONAL NO BRASIL DA MOBILIDADE SOCIAL}

\section{Moisés Kopper}

Palavras-chave: Políticas públicas; Cidadania; Merecimento; Pós-vidas; Subjetividade; Habitação.

Políticas econômicas e sociais construíram o caminho para a redução das desigualdades e melhoria de vida de milhốes de brasileiros nos anos de 2000 . Com base em pesquisa entre recipientes do programa Minha Casa, Minha Vida, discute-se os nexos etnográficos entre políticas públicas e mobilidade ascendente. Seguindo a trajetória pública e privada de dona Hilda - uma senhora negra e pobre de 97 anos que vive na periferia de Porto Alegre - argumento que a mobilidade emergente no cerne da ampliação das intervençóes de governo materializou-se em alinhamentos difusos entre políticos locais, agentes de mercado, planejadores, lideranças e "cidadãos desejantes". Para navegar esses terrenos políticos, econômicos e comunitários, dona Hilda engajou-se num trabalho por cidadania habitacional e merecimento que a converteu na personagem exemplar do programa. Deslindando os limites morais entre discurso, história e subjetividade, a cartografia desses fragmentos está mais bem equipada para explorar as pós-vidas das políticas públicas no Brasil recente.

\section{PUBLIC POLICIES AND THEIR AFTERLIVES: WORTHINESS AND HOUSING CITIZENSHIP IN BRAZIL}

\section{Moisés Kopper}

Keywords: Public policies; Citizenship; Worthiness; Afterlives; Subjectivity; Housing.

Economic and social policies paved the way for inequality alleviation and wellbeing improvements in the lives of millions during the 2000s in Brazil. Drawing from ethnography conducted among recipients of the housing program Minha Casa, Minha Vida ["My House, My Life"], this article examines the ways public policies intersect with upward mobility. Charting the public and private trajectories of dona Hilda [Mrs. Hilda] - a 97-year-old poor black woman living in the periphery of Porto Alegre - I argue that mobility arising from within the widened scope of state interventions produced multiscale alignments between local politicians, marketers, planners, community leaders, and desiring citizens. To navigate this political, economic, and communitarian terrains, dona Hilda engaged in a laborious work for housing citizenship and worthiness that converted her into the program's exemplarycharacter. Unraveling the moral boundaries at the juncture of discourse, history and subjectivity, the cartography of subjective fragments is best suited to explore the lingering afterlives of public policies in present-day Brazil.

\section{LES POLITIQUES PUBLIQUES ET LEURS APRÈS-VIE: LE MÉRITE ET LA CITOYENNETÉ HABITATIONNELLE AU BRÉSIL DE LA MOBILITÉ SOCIALE}

\section{Moisés Kopper}

Mots-clés: Politiques publiques; $\mathrm{Ci}$ toyenneté; Mérite; Continuité; Subjectivité; Logement.

Les politiques économiques et sociales ont construit la voie vers la réduction des inégalités et l'amélioration de la vie de millions de Brésiliens dans les années 2000. Grâce aux recherches existantes parmi les bénéficiaires du programme Minha Casa, Minha Vida (Ma Maison, $\mathrm{Ma} \mathrm{Vie}$ ), nous abordons les liens ethnographiques entre les politiques publiques et la mobilité ascendante. Nous avons accompagné la trajectoire publique et privée de Mme. Hilda - une femme au foyer, noire, pauvre, de 97 ans, vivant dans la banlieue de Porto Alegre - grâce à laquelle nous soutenons que la mobilité émergente au cœur de l'expansion des interventions gouvernementales s'est matérialisée pardes alignements diffus entre les politiciens locaux, les agents économiques, les planificateurset les « citoyens désirants ". Pour s'insérer dans ces terrains politiques, économiques et communautaires, Mme Hilda s'est engagée dans un travail pour la citoyenneté habitationnelle et le mérite, ce qui l'a convertie en un personnage exemplairede programme. En élucidant les limites morales entre le discours, l'histoire et la subjectivité, la cartographie de ces fragments est mieux outillée pour exploiter la continuité des politiques publiques au Brésil actuel. 